Sound and Sight 



\section{Sound and Sight}

P O E T R A N D

COURTIER CULTURE IN THE

YONGMING ERA $(483-493)$

Meow Hui Goh

STANFORD UNIVERSITY PRESS

$S$ T A N F O R D, C A L I F O R N I A 
Stanford University Press

Stanford, California

(C) 2010 by the Board of Trustees of the Leland Stanford Junior University.

All rights reserved.

No part of this book may be reproduced or transmitted in any form or by any means, electronic or mechanical, including photocopying and recording, or in any information storage or retrieval system without the prior written permission of Stanford University Press.

Printed in the United States of America on acid-free, archival-quality paper

Library of Congress Cataloging-in-Publication Data

Goh, Meow Hui.

Sound and sight : poetry and courtier culture in the Yongming era (483-493) / Meow Hui Goh.

p. $\mathrm{cm}$.

Includes bibliographical references and index.

ISBN 978-0-8047-6859-7 (cloth : alk. paper)

I. Chinese poetry--Northern and Southern dynasties, 386-589--History and criticism.

2. Sensuality in literature. 3. Senses and sensation in literature. 4. China--Court and courtiers. I. Title.

PL2319.G64 2010

895.I'I209--dc22

2010018634

Typeset by Bruce Lundquist in 10.5/14 Adobe Garamond 
For Keoni 
